\title{
KOREAN SIJO POEMS AND THEIR TRANSFORMATIONS
}

\author{
Kyong-geun $\mathrm{OH}$ \\ Institute of Linguistics \\ Department of Korean Studies \\ Adam Mickiewicz University in Poznań \\ okg615@gmail.com
}

\begin{abstract}
Sijo is an original genre of short Korean poems with a strictly defined structure reflecting the rhythm of a traditional Korean song. Sijo poems are the only traditional genre of Korean poetry, which is still practised by contemporary Korean poets. It gained tremendous popularity during the reign of the Joseon dynasty, especially among the Confucian scholars and noblemen who ruled the country. Sijo poetry has undergone a transformation as far as the topics and structure of sijo poems are concerned. Initially the authors of sijo belonged to the ruling class and were solely men (Confucian scholars). But with the passage of time and the development of society the representatives of the middle class started writing sijo poems as well. The sijo transformations also included the linguistic changes, which may be observed through the course of sijo history. The topics also changed as new types of sijo appeared beside traditional sijo devoted mainly to Confucian ideas formulated in a refined language.
\end{abstract}

Keywords: Sijo, Dan-sijo, Yeon-sijo, Saseol-sijo, Gangho-sijo, Gyohun-sijo, Gagaeksijo, Confucianism, Confucian scholar, Gisaeng

\section{한국의 전통시가 시조의 변화상}

개요: 시조는 한국 전통시가의 운율을 바탕으로 엄격하게 규정된 형태와 구조를 지닌 한국 고유의 단시이다. 시조는 한국의 전통시가들 중에서는 유일하게 현재까지도 창작되는 장르이다. 조선시대에 시조는 지배계급이었던 사대부- 
유학자들 사이에서 크게 애호되었다. 시조는 그 역사 속에서 주제 및 형태가 변화되었다. 애초에 시조의 작가들은 지배계급인 양반-사대부 남성들에 국한되었으나, 시간이 지나고 사회가 발전 변화함에 따라 중인계층의 사람들도 시조를 창작하게 되었으며 여성으로서는 유일하게 기생이 동참했다. 고상한 언어로 주로 유교이념을 표현하던 전통시조 이외에 새로운 형태의 시조들이 나타남에 따라 시조의 언어는 물론 주제 또한 변하게 되었다.

키워드: 시조, 단시조, 연시조, 사설시조, 강호시조, 교훈시조, 가객시조, 유교, 사대부, 기생

\section{Introduction}

Sijo is an original genre of short Korean poems with a strictly defined structure reflecting the rhythm of a traditional Korean song. So one may say that sijo is the most indigenous Korean poem. Its form is very different from poems found in foreign literature. It is a genre with the longest tradition in the history of Korean poetry, which in fact means that despite its short form (it is a poem composed of three lines); it is the most important type of poetry among traditional Korean poetry genres. Additionally, it should be stressed here that sijo poems are the only traditional genre of Korean poetry, which are still written by contemporary Korean poets.

In the period of modernisation at the end of the $19^{\text {th }}$ century and the beginning of the $20^{\text {th }}$ century Koreans, without any reservation, accepted European science and civilization also copying European literary genres, which to some extent caused the relegation of traditional Korean literature to the sidelines or the verge of extinction. It may be even said that almost all traditional literary genres ceased to exist with the exception of sijo, which was saved for future generations by being incorporated into the so-called "modern literature" under the name of "modern sijo".

This paper has been written for foreigners and persons dealing with Korean literature abroad to give them some insight into a specific form, the structure and artistic beauty of sijo. The author also discuss- 
es the changes of the format, topics and authors in the course of the history of sijo development and transformation.

\section{Emergence and development of sijo poems}

Sijo poems were first written at the end of the Goryeo dynasty (about the $14^{\text {th }}$ century). When the Goryeo dynasty became extinct, and a new dynasty, the Joseon dynasty, was established with the Confucian ideology, sijo had become the most popular type of poetry among the ruling Confucian scholars and noblemen. It gained tremendous popularity during the reign of the Joseon dynasty.

Sijo was primarily private poetry written in Korean as it was very suitable for expressing one's own feelings and thoughts. Additionally, due to the rhythm, it was very easy to be sung. For a very long time scholars and noblemen wrote poems called hansi. This poetic form was written in Chinese characters and was not readily adaptable for singing. Hansi was written by the social elite, who wished to emphasise their superiority over the other social classes (that it was the erudite class of society able to read and write Chinese characters). Such poems could be recited, as it was extremely difficult to sing them in a foreign language. Therefore, sijo became the main genre of Korean literature, also for the nobility (Gyojae pyeonchan uiwonhoe 1996: 70).

Generally one may distinguish two stages in sijo development, that is to say: 1) till 1876 (the period of Korean isolation, when the socalled traditional sijo was created), 2) after 1876 when the so-called modern sijo was created.

Until the end of Joseon dynasty there was no one name for this type of poetry. There were various names in use and each of them was used depending of the situation in which the poems were sung: for instance the song - ga (가, 歌), gagok (가곡, 歌曲), gayo (가요, 歌謠 ), the short song - dan-ga (단가, 短歌), mode of singing this type of poems - sijo (시조, 時調), sijeolga (시절가, 時節歌), sijeol-dan-ga (시절단가, 時節短歌) etc. The name sijo was not used as a name for 
a literary genre but only as a name for a specific form of a song. Therefore the following Chinese characters were used to name it: '時 調' (sijo 'new style of music') instead of '詩調' (sijo 'genre of literature') (Seong Giok, Son Jongheum 2008: 253). So in order to understand sijo properly one needs to understand its features of the song.

'Sijo' is an official name of this genre of poems, which started being used in the period of modernism especially when the so-called "Movement for the restoration of sijo" became active in the second decade of the $19^{\text {th }}$ century. The activists of the movement copied the first part of the name of the music sijochang (시조창, 時調唱), which emerged in the mid $18^{\text {th }}$-century as a new mode of singing poems called sijo. Sijochang was a new style of music, which was easy to sing and which could be sung not only by musicians but also by the general population. The song was also composed of three lines similarly to sijo poems (Seong Giok, Son Jongheum 2008: 255, 259-260).

\section{Structure and rhythm of sijo}

\subsection{The structure of typical sijo}

Hyang-ga, Gyeong-gi-che-ga, gasa, sijo are traditional Korean poems, which have a very fixed form. Of these three, sijo has the most precisely formulated form and rhythm. That is why it may be stated that the secret of the beauty of sijo as a poem is intrinsic in its strictly defined form and verse structure. The taste and artistic beauty of those poems results from their elegant and noble mode of expressing the emotions of an individual in a very succinct form.

Pyeong-sijo is the most typical version of sijo having the following syllabic structure: 


$\begin{array}{lllll}\text { verse 1: } & 3 & 4 & \underline{\mathbf{3}[\mathbf{4}]} & 4 \\ \text { verse 2: } & 3 & 4 & \underline{\mathbf{3}[\mathbf{4}]} & 4 \\ \text { verse 3: } & 3 & \mathbf{5} & 4 & 3\end{array}$

Sijo poems are composed of three verses. This constitutes a proof that these poems are the direct successors of the long poetic tradition of Korea in which one may observe literary pieces with three verses where the last line ends with an exclamation mark.

The most typical sijo is composed of 12 rhythmic units (four units in each verse) which amount to about 45 syllables - usually with 15 syllables in each verse. There are also less typical forms of sijo having from 41 to 50 syllables. The syllables in the first and second verse may be grouped into arbitrarily chosen combinations of three and four- syllable units.

However, the third verse was composed of the strictly obeyed sequence of syllable units (3 543 ), even if the naturalness of speech was affected.

Each verse is divided into two thematic units, which may be compared to sentences. Each thematic unit is composed of two rhythmic units. Therefore, a classical sijo poem is composed of six thematic units devoted to one topic.

Additionally, the structure of sijo is based on the following rhythm 'repetition - change', which means that the first and second verses are the same as far as the number and length of rhythmic units are concerned, whereas the third one is different as its second rhythmic unit is twice as long as other rhythmic units.

$\begin{array}{llllll}\text { first verse: } & 4 & 4 & / / & 4 & 4 \\ \text { second verse: } & 4 & 4 & / / & 4 & 4-\text { repetition } \\ \text { third verse: } & 4 & \underline{4+4} & / / & 4 & 4-\text { change }\end{array}$

Such structure serves the purpose of expressing emotions and thoughts, which are expressed in the first and second verses by summing them up in the last one where the rhythm is changed (Seong Giok, Son Jongheum 2008: 288-289). In other words the author expresses some concept or a poetic thought in the first and second verses but it is precisely formulated no sooner than the third one. Thus, the poetic imagination or the topic, which is expressed in the first and 
second verses has no specific poetic significance and does not transfer any information needed to understand the ideas. Those concepts are realised in the last verse so without it the reader cannot understand the poem and the poetic concept of the author. This is the essence of the specific structure of sijo.

The structure based on 'repetition - change' is not only the external scheme for sijo, but it is also the source of the artistic power of creation. Because of that sijo, which is the shortest among Korean poems, is also the best organised as far as its structure is concerned. The structure is very useful for intense expression of the features of objects described by the author and it also reveals the most characteristic features of sijo.

\subsection{The rhythm of typical sijo}

Typical sijo is a short form, which is composed of three verses and each verse is composed of four rhythmic units. Each rhythmic unit is of the same length. The length is not measured in the number of syllables but in the length of the rhythm. In other words one rhythmic unit may be composed of two, three, four or even five syllables but as far as pronunciation is concerned the length is always the same. The length of the rhythmic unit is not dependent on the number of syllables.

The rhythm of typical sijo is established by dividing the poem into 6 sentences (thematic units) composed of 12 rhythmic units:

$\begin{array}{llllll}\text { verse 1: } & 3 & 4 & / / & 3[4] & 4 \\ \text { verse 2: } & 3 & 4 & / / & 3[4] & 4 \\ \text { verse 3: } & 3 & 5 & / / & 4 & 3\end{array}$

As one sees from the example presented above, rhythmic units are composed of 3,4 or 5 syllables. Rhythmic units in the first and second verses are composed of three or four syllables, and in the third verse of three, four or five syllables. Despite the fact that the number 
of syllables in a rhythmic unit may vary from 3 to 5 , their recitation length, as already mentioned, is the same. Because the longer or shorter rhythmic units are sung or recited quickly or slowly to make them of equal length.

\section{Example of typical sijo}

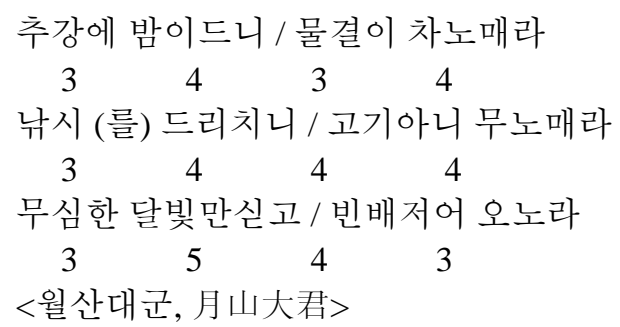

Night is on the autumn river / the water is cold

I cast a line / but fish do not bite

I row back an empty boat / loaded with unfeeling moonlight.

$<$ Prince Wolsan>

\section{Types of sijo}

In general, there are two main types of sijo:

1. Pyeong-sijo (dan-sijo - typical short sijo, yeon-sijo - complex of dan-sijo)

2. Saseol-sijo (long sijo or the so-called prosaic sijo)

Pyeong-sijo is standard and simultaneously the proper type of sijo. It was the most proper type of the song, which was used by Confucian scholars in order to express their emotions and thoughts in an intense and improvised way. It was possible due to the short form of these poems.

Pyeong-sijo may be divided into dan-sijo and yeon-sijo. Dan-sijo is a typical sijo, which has already been discussed in detail above. 


\section{Yeon-sijo}

It should be stressed here that due to their length dan-sijo poems were too short to express much in them. Therefore, one may also encounter the so-called complex sijo poems that is to say a few sijo poems, generally from three to ten, joined into a longer poem, in which the stanzas are separate sijo poems creating together one thematic whole. Such combinations of sijo poems are called yeon-sijo.

The poems are usually arranged in accordance with 1) time (for instance the four seasons of the year), 2) space (for instance they describe the beauty of places or areas visited), 3) Confucian ethical rules (for instance the five moral disciplines in relations between people). It should be remembered here however that each poem had a personal nature and could be sung separately. In general, sijo was written for singing rather than reading and a poem for singing does not need to be very long. Contemporary songs are very similar in this respect.

The number of yeon-sijo is definitely more limited than dan-sijo and the majority of authors were Confucian scholars. As far as the quality is concerned, there are many better yeon-sijo than dan-sijo (Seong Giok, Son Jongheum 2008: 301). So the majority of sijo, which are highly valued in Korean literature, are yeon-sijo.

Example of yeon-sijo

$$
\begin{array}{lc}
\text { 강호에 봄이드니 미친흥이 절로난다 } & \text { [봄, spring] } \\
\text { 탁료계변에 금린어 안주로다 } & \\
\text { 이 몸이 한가하옴도 역군은 이샷다 } & \\
\begin{array}{l}
\text { 강호에 녀름이 드니 초당에 일이 업다 } \\
\text { 유신한 강파는 보내나니 바람이로다 }
\end{array} & \text { [여름, summer] } \\
\text { 이 몸이 서늘하옴도 역군은 이샷다 } & \\
\text { 강호에 가을이 드니 고기마다 살져잇다 } & \text { [가을, autumn] } \\
\text { 소정에 그믈 시러 흘려 띄여 더뎌 두고 } & \\
\text { 이몸이 소일하옴도 역군은 이샷다 } & \\
\text { 강호에 겨울이 드니 눈기픠 자히남다 } & \text { [겨울, winter] } \\
\text { 삿갓 빗기 쓰고 누역으로옹슬 삼아 } & \\
\text { 이 몸이 칩지 아니하옴도 역군은 이샷다 } &
\end{array}
$$


<강호사시가 - 맹사성>

Spring has arrived, so joyful it is

I play at the bank of the stream, enjoying my wine and fish

My life is so comfortable thanks to my gracious king

Summer has arrived, I have nothing to do in my hut

The faithful river sends me wind,

Fresh wind thanks to my gracious king

Autumn has arrived, the fish are fat

I take my fishing net to the boat, I throw it anyhow

I can live so peacefully thanks to my gracious king

Winter has arrived, a thick cover of snow is everywhere

I will put on my straw hat askew, my straw coat

It is not cold thanks to my gracious king

<Gangho sasiga - Maeng Saseong>

\section{Saseol-sijo}

Saseol-sijo emerged in specific conditions in the second half of the dynasty of Joseon, when long poems flourished and negative phenomena of social structures started to become visible as a result of which the old social divisions were to collapse. Most of the saseol-sijo were written anonymously so one cannot discuss their authors. However, taking into consideration different conditions and circumstances, one may state that their authors were usually people from the middleclass (Jo Dong-il, Seo Jongmun, Pak Jongseong 2012: 323-324).

Saseol-sijo differs from pyeong-sijo. It is longer and that is why it is also called a long sijo. It is too long to explain its character with the logical formality of pyeong-sijo. Although it is still composed of three verses, the number of rhythmic units in a verse is not determined. Typical of that type of sijo is the rhythm of recitation, which results from the division into rhythmic units recited between breaths.

The long form changed the nature of sijo and resulted in the emergence of specific aesthetic values distinguishing it from pyeongsijo. It is the aesthetics of 'divergence/deviation' acquired by awakening and separation from the aesthetics of pyeong-sijo, which boasts 
cleanliness, elegance and nobility. Long words written in saseol-sijo are usually rhetorical tools helping to reveal emotions. In other words it is the exaggeration by long enumerations. It is the linguistic tool and the pathos of laughter. Therefore the typical features of the aesthetics of saseol-sijo include nimbleness, fun and caricature, et cetera.

However, saseol-sijo rarely diverges from the poetic world of pyeong-sijo, which expresses momentous emotions or internal feelings for the same mood or one idea.

\section{Example of saseol-sijo}

First verse: 바둑이 검둥이 청삽사리 중에 조 노랑 암캐 같이 얄밉고 잣믜오랴

Second verse: 미운 님 오게되면 꼬리를 회회치며 반겨 내닫고 고은 님이 오게되면

두 발을 벗띄듸고 코쌀을 찡그리며 무르락 마오락 캉캉 즛난 요 노랑 암캐

Third verse: 이튿날 문밖에 개 사옵새 웨난 장사 가거드란 찬찬 동혀 내야 쥬리라

<육당본, 청구영언>

First verse: Spotted dog and black dog and shaggy blue hound — but this yellow bitch is the wiliest in the pack.

Second verse: Comes an unwanted guest, she'll wag her tail with pleasure and follow behind his heels, but for a friend of mine she'll stiffen her legs and bare her teeth and bark her head off.

Third verse: You yellow bitch! Tomorrow if I hear that man outside shouting "Any dogs for sale?" I will tie you and sell you straight for dog meat.

(Translation from The Bamboo Grove: An Introduction to Sijo edited by Richard Rutt: 231) 


\section{Topics of sijo}

Sijo may be topically divided into

1) gangho-sijo (강호시조),

2) gyohun-sijo (교훈시조),

3) uguk-sijo (우국시조),

4) aejeong-sijo (애정시조).

It should be remembered that in the majority of cases the authors and lovers of sijo were Confucian scholars.

Sadaebu (사대부, 士大夫), Confucian scholars, were people who constituted a new political power. They used Confucian ideology at the end of the Goryeo dynasty. They finally managed to overthrow the old dynasty and establish a new, Joseon dynasty (1392-1910). Forming an actual ruling power, they could decide the shape of politics, society, culture, etc. Their sijo is much more philosophical and ideological than the poems written by people from the middle-class or gisaeng. The presented ideology is usually limited to Confucian ideology.

Consequently, the poems presenting Confucian ideology were developed in two main directions: 1) gangho-sijo (강호시조) and 2) gyohun-sijo (교훈시조) (Seong Giok, Son Jongheum 2008: 332-333).

Gangho-sijo is the main genre written by the ruling class of noblemen (called: sadaebu) about 강호한정 (江湖閑情, gang-ho-hanjeong, lit. quiet life close to the nature). So they were devoted to 'Quiet and happy life close to the nature'. They sung about the delights of rural life in harmony between men and nature.

It was not only a song about a quiet and happy life close to nature, about resting and having fun or about human life. Poems revealed the increased interest in nature of the sadaebu. Gangho-sijo expressed the torments that they suffered in their private lives as scholars living among society.

Gyohun-sijo primarily expresses duties in inter-human relations, which must be fulfilled in order to make people live in harmony. In other words, it was a social poetry which was written to teach people morals and ethics. 
It may seem that gangho-sijo and gyohun-sijo are two opposing poles, with different aspirations that is to say on the one hand perfecting oneself and on the other hand teaching others. However, if one looks at them from the Confucian point of view and Confucian teachings, one quickly realises that a human being must first perfect oneself and only after achieving that objective may he start teaching others. So those two aspects are always inter-related, combined together as two sides of a coin and that is why they became the main topics of sadaebu-sijo (Gyojae pyeonchan uiwonhoe 1996: 75).

Uguk-sijo (우국시조) is devoted to social problems discussed from the point of view of the ruling class.

Especially in the second half of the Joseon dynasty, after the war with Japan (in 1592) and China (in 1676), the poets frequently wrote about Confucian ideology and the bravery of men fighting for their country.

Uguk-sijo content definitely focuses on the anger and sorrow suffered by the author who was unable to save and protect his motherland. It may also be devoted to the criticism of the ruling class who, after the war, stopped fighting for the freedom of their own nation and country and continued quarrelling about power.

Aejeong-sijo (애정시조) are poems written primarily by gisaeng. In general the authors of sijo were men. As far as women are concerned, the only ones who wrote sijo were Korean gisaeng.

Gisaeng lived in a specific social situation at that time. They formally were classed as people of the lower social classes. But among women they were the only ones who could join noble men in their social lives. That is why apart from being taught how to sing and dance, they also had to be able to read and write poems in Chinese characters in order to enable the men, Confucian scholars, to enjoy their time. In other words, their education was the highest among women. Therefore, they also needed to be very intelligent. It was a prerequisite for them to be able to know sijo very well because during various parties and festivities they were singing sijo written by men. Sijo poems written by them reflected the specific social status they enjoyed. It means that their poems were devoted mostly to tragic love they experienced, their tragic fate - they were officially forbidden to marry so love and marital maternity were beyond their reach. That is 
why they generally sang about sorrow or suffering resulting from parting with a beloved one, and love, which could not be continued.

Sijo poems written by them were devoted to love and the problem of burning, hopeless and forbidden love (misery of separation of lovers, solitude, waiting for the beloved man, etc.)

The Confucians did not write about love as they considered the topic improper. According to them sijo poems should be refined and full of dignity. But gisaeng were not afraid to write about the taboo topic and thus they enriched the range of topics of sijo.

As they were not ashamed to sing in public about love, which was treated as a taboo topic by the noble scholars, they managed to achieve the freedom and liberty of poetic tenderness in the world of sijo. Writing about love, beauty and nostalgia, lingeringly they were able to create a beautiful and artistic mood in their poems.

Sijo by gisaeng Hwang Ji-ni (her dates of birth and death are unknown), who is the most famous gisaeng for her beauty, intellect and artistic skills living in the times of Joseon dynasty:

$$
\begin{aligned}
& \text { 동짓달 기나긴밤 한 허리를 버혀내어 } \\
& \text { 춘풍 니불 아래서리서리 너헛다가 } \\
& \text { 어론님 오신날 밤이여든 구뷔구뷔 펴리라 }
\end{aligned}
$$

I wish I could cut out the waist of this deep mid-winter night And curl it softly, softly under the warm spring quilt And slowly, slowly spread it on the night my love comes back (Love in mid-winter night 1985: 37)

In the second half of the rule of the Joseon dynasty (at the end of the $17^{\text {th }}$ century and in the $18-19^{\text {th }}$ centuries) sijo poems begin to describe the feelings of men and their contemporary life. The change in the topics was mostly caused by the fact that among the authors of sijo, next to the noblemen, one may also find the representatives of the middle class.

In the second half of the $18^{\text {th }}$ century there were numerous great singers and poets such as Kim Cheon-taek and Kim Su-chang among others who could sing and write sijo very well. There were also those such as Lee Se-chun, who were professional singers of sijo. Sijo created by them is called gagaek-sijo (가객시조). Due to the rapid devel- 
opment of commerce and entertainment culture in the $18^{\text {th }}$ century they became the main lovers of sijo in cities and they exerted an important influence on its fundamental transformation in the second half of the Joseon dynasty.

In general the world of gagaek-sijo does not differ much from saedabu-sijo. It is so because their authors usually wanted to imitate the culture of higher classes that is to say sadaebu. They did not write gyohun-sijo or uguk-sijo, which discussed teaching the masses or worrying about the motherland. Teaching people and protecting the country are the tasks of the ruling class. That is why gangho-sijo written by them usually presents the image of an extra-terrestrial nature rather than harmony with nature (which is typical of sijo written by $s a$ daebu). They usually concentrated on pleasure derived from human life spent in such nature. It means that they wrote directly about the beauty of nature.

\section{Summary}

To summarise, sijo poetry has undergone a transformation as far as the topics and structure of sijo poems are concerned.

Initially the authors of sijo belonged to the ruling class and were solely men (Confucian scholars). With the passage of time and the development of society the representatives of the middle class started to write sijo poems as well. But in the history of sijo the most famous and highly regarded sijo poets were: rulers and noblemen (Confucian scholars).

First the rhythm of sijo poems was changed as the authors departed from the strict rhythmic units in particular verses. Next, the long sijo developed in which even the length of verses was not limited by the number of rhythmic units at all. The sijo transformations also included the linguistic changes, which may be observed in the course of sijo history. The topics also changed as new types of sijo appeared adjacent to traditional sijo devoted mainly to Confucian ideas formulated in a ponderous language. The new types of sijo were devoted to 
daily life of people, sometimes were even coarse or vulgar and were written mainly by ordinary people.

A poem with a fixed form may have artistic beauty, which is built in the course of long history. Sijo is a poem with such fixed form making it sophisticated and beautiful. Therefore, it has its poetic value and there are reasons why it exists as a poetic genre.

What is typical of sijo is the regular number of rhythmic units, which are composed of syllables. Some poems of modern sijo frequently omit that and as a result cannot retain the beauty of rhythmic sijo. They focus on the revival of sijo, but claim that its traditional fixed form cannot be preserved (Lim Jongchan 1996: 298). However, a poem with a fixed form, contrary to free verse, must adhere to the rhythm. Otherwise, it is no longer a fixed verse poem. Thus, sijo, even a contemporary one, which does not obey the form, cannot be considered sijo.

What distinguishes a free verse from a fixed verse is the rhythm, which constitutes a specific artistic beauty. So the real beauty of sijo stems from its fixed verse form and harmony between its form and contents. If sijo imitates the structure of free verse, it loses its artistic beauty and the reason for its existence. To conclude, one may not agree with some contemporary poets who claim that the traditional form of sijo is too complicated and difficult to express poetic contents.

\section{Bibliography}

Bae Gyubeom, Ju Okpa, 2010. 『외국인을 위한 한국고전문학사』. 서울: 도서출판 하우.

Chung Chong-wha, trans. 1985. Love in mid-winter night: Korean Sijo Poetry. London: KPI.

Gang Insu, 2003. 『한국문학의 이해』. 서울: 삼영사.

Gyojae pyeonchan uiwonhoe [교재편찬위원회 편], 1996, 『한국문학의 이해』. 부산: 세종출판사.

Hwang Paegang, 1998. 『한국문학의이해』. 서울: 새문사. 
Jeong Daerim, Kwon Yongju, 2006. 『한국문학의 이해와 감상』. 서울: 동방도서.

Jo Dong-il et al., 2005. 『한국문학강의』. 서울: 길벗.

Jo Dong-il, Seo Jongmun, Pak Jongseong, 2012. 『국문학의 역사』. 서울: KNOU PRESS

Kim Hakdong, 2009. 『개화기시가 연구』. 서울: 새문사.

Lee Changsik, 2010. 『다문화시대 한국어교육을 위한 한국문학의 이해』.서울: 도서출판 박이정.

Lim Jongchan, 「현대시조의 구조적 이해」. 부산: 세종출판사.

Ruth, Richard ed. 1998. The Bamboo Grove: An Introduction to Sijo. Michigan: University of Michigan Press.

Seong Giok, Son Jongheum, 2008 『고 전 시 가 론』. 서울:한국방송통신대학교출판부.

Son Jongheum, 2002.『 고 전 문 학 기 행』. 서울: 한국통신대학교출판부.

Yun Deokjin, Son Jongheum, 2007. 『고전시 가강독』. 서울: KNOU PRESS. 